ARTICLE

\title{
The contribution of water radiolysis to marine sedimentary life
}

\author{
Justine F. Sauvage ${ }^{1,5 凶}$, Ashton Flinders (10 ${ }^{2}$, Arthur J. Spivack ${ }^{1}$, Robert Pockalny (D) ${ }^{1}$, Ann G. Dunlea (D) ${ }^{3}$, \\ Chloe H. Anderson (10 ${ }^{4}$, David C. Smith (D) ${ }^{1}$, Richard W. Murray ${ }^{3} \&$ Steven D'Hondt (10 ${ }^{1}$
}

Water radiolysis continuously produces $\mathrm{H}_{2}$ and oxidized chemicals in wet sediment and rock. Radiolytic $\mathrm{H}_{2}$ has been identified as the primary electron donor (food) for microorganisms in continental aquifers kilometers below Earth's surface. Radiolytic products may also be significant for sustaining life in subseafloor sediment and subsurface environments of other planets. However, the extent to which most subsurface ecosystems rely on radiolytic products has been poorly constrained, due to incomplete understanding of radiolytic chemical yields in natural environments. Here we show that all common marine sediment types catalyse radiolytic $\mathrm{H}_{2}$ production, amplifying yields by up to $27 \mathrm{X}$ relative to pure water. In electron equivalents, the global rate of radiolytic $\mathrm{H}_{2}$ production in marine sediment appears to be $1-2 \%$ of the global organic flux to the seafloor. However, most organic matter is consumed at or near the seafloor, whereas radiolytic $\mathrm{H}_{2}$ is produced at all sediment depths. Comparison of radiolytic $\mathrm{H}_{2}$ consumption rates to organic oxidation rates suggests that water radiolysis is the principal source of biologically accessible energy for microbial communities in marine sediment older than a few million years. Where water permeates similarly catalytic material on other worlds, life may also be sustained by water radiolysis.

\footnotetext{
${ }^{1}$ Graduate School of Oceanography, University of Rhode Island, Narragansett, RI, USA. ${ }^{2}$ United States Geological Survey, Hawaiian Volcano Observatory, Hilo, HI, USA. ${ }^{3}$ Woods Hole Oceanographic Institution, Woods Hole, MA, USA. ${ }^{4}$ MARUM - Center for Marine Environmental Sciences, University of Bremen,

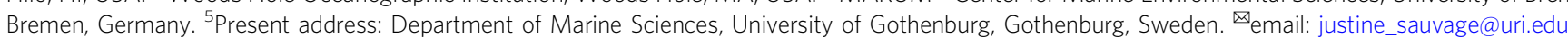


R adionuclides are ubiquitous in sediment and rock, where their decay leads to hydrogen $\left(\mathrm{H}_{2}\right)$ and oxidant production via radiolysis of water ${ }^{1-4}$. Radiolytic yields in pure water are well constrained ${ }^{5,6}$ and some monominerals (pyrite, various oxides, mordenite, calcite) are known to amplify water-radiolytic $\mathrm{H}_{2}$ yields when irradiated by $\gamma$ rays $^{7-9}$. Similarly, other oxides and calcite enhance water-radiolytic $\mathrm{H}_{2}$ production following exposure to a particles ${ }^{9-11}$. The effect of mineralogically complex natural materials on $\mathrm{H}_{2}$ yields is previously unexplored.

Hydrogen $\left(\mathrm{H}_{2}\right)$ and oxidants generated by natural radiolysis of water provide a continuous source of chemical energy for subsurface ecosystems ${ }^{2-4,12,13}$. Microbial life persists deep beneath Earth's surface ${ }^{14,15}$ and constitutes a significant fraction of Earth's total biomass ${ }^{16,17}$. Radiolytic $\mathrm{H}_{2}$ is now recognized as the primary electron donor for microbial communities kilometers below the surface in Precambrian regions of continental lithosphere ${ }^{14}$. However, the extent to which most subsurface ecosystems rely on radiolytic products has been unclear because (i) radiolytic chemical yields in natural environments have been poorly constrained and (ii) organic matter and oxidants from the surface photosynthetic world are pervasive in many subsurface environments.

\section{Results and discussion}

We experimentally quantified $\mathrm{H}_{2}$ yields for $\alpha$ - and $\gamma$-irradiation of pure water, seawater, and seawater-saturated marine sediment with a typical abyssal clay porosity (80-85\%) for all abundant marine sediment types (abyssal clay, nannofossil-bearing clay (calcareous marl), clay-bearing siliceous ooze, calcareous ooze, and lithogenous sediment), which collectively cover $\sim 70 \%$ of Earth's surface.

Our results show that for pure water, seawater, and marine sediment slurries, $\mathrm{H}_{2}$ production increases linearly with absorbed $\alpha$ - and $\gamma$-ray dose. Energy-normalized radiolytic $\mathrm{H}_{2}$ yields, denoted by $\mathrm{G}\left(\mathrm{H}_{2}\right)$ (molecules $\mathrm{H}_{2}$ per $100 \mathrm{eV}$ absorbed) ${ }^{1}$, in seawater are indistinguishable from those in pure water, within the $90 \%$ confidence limit of our experiments. In contrast, $\mathrm{G}\left(\mathrm{H}_{2}\right)$ values of marine sediment slurries are consistently higher than values for pure water (Fig. 1). The catalytic effect of marine sediment on radiolytic yield is significant for both $\alpha$ - and $\gamma$-irradiation, but much larger for $\alpha$-irradiation. Alpha-irradiation $\mathrm{G}\left(\mathrm{H}_{2}\right)$ values for abyssal clay slurries are more than an order of magnitude higher than for pure water. On average, claybearing siliceous ooze and calcareous marl increase $\mathrm{G}\left(\mathrm{H}_{2}\right)$ for a-irradiation by factors of 15 and 12, respectively. Calcareous ooze increases yields by a factor of 5 for $\alpha$-irradiation. For $\gamma$-irradiation, clay-bearing siliceous ooze and abyssal clay amplify $\mathrm{G}\left(\mathrm{H}_{2}\right)$ by factors of 8 and 4 , respectively. Calcareous ooze and marl slurries doubled $\mathrm{G}\left(\mathrm{H}_{2}\right)$ for $\gamma$-irradiation. These results demonstrate that (i) all common marine sediment types catalyze radiolytic $\mathrm{H}_{2}$ production, and (ii) the magnitude of this catalysis depends on sediment composition and radiation type.

Previous experiments with oxides suggest that the primary cause of increased yield in all of our sediment types is energy transfer from sediment particles to the water via excitons ${ }^{18-20} \cdot \mathrm{H}_{2}$ yield exceeds the pure-water yield for $\gamma$-irradiated oxides characterized by a band gap equal to the $5.1 \mathrm{eV}$ energy of the $\mathrm{H}-\mathrm{OH}$ bond in water ${ }^{18}$. This result is consistent with irradiation of the

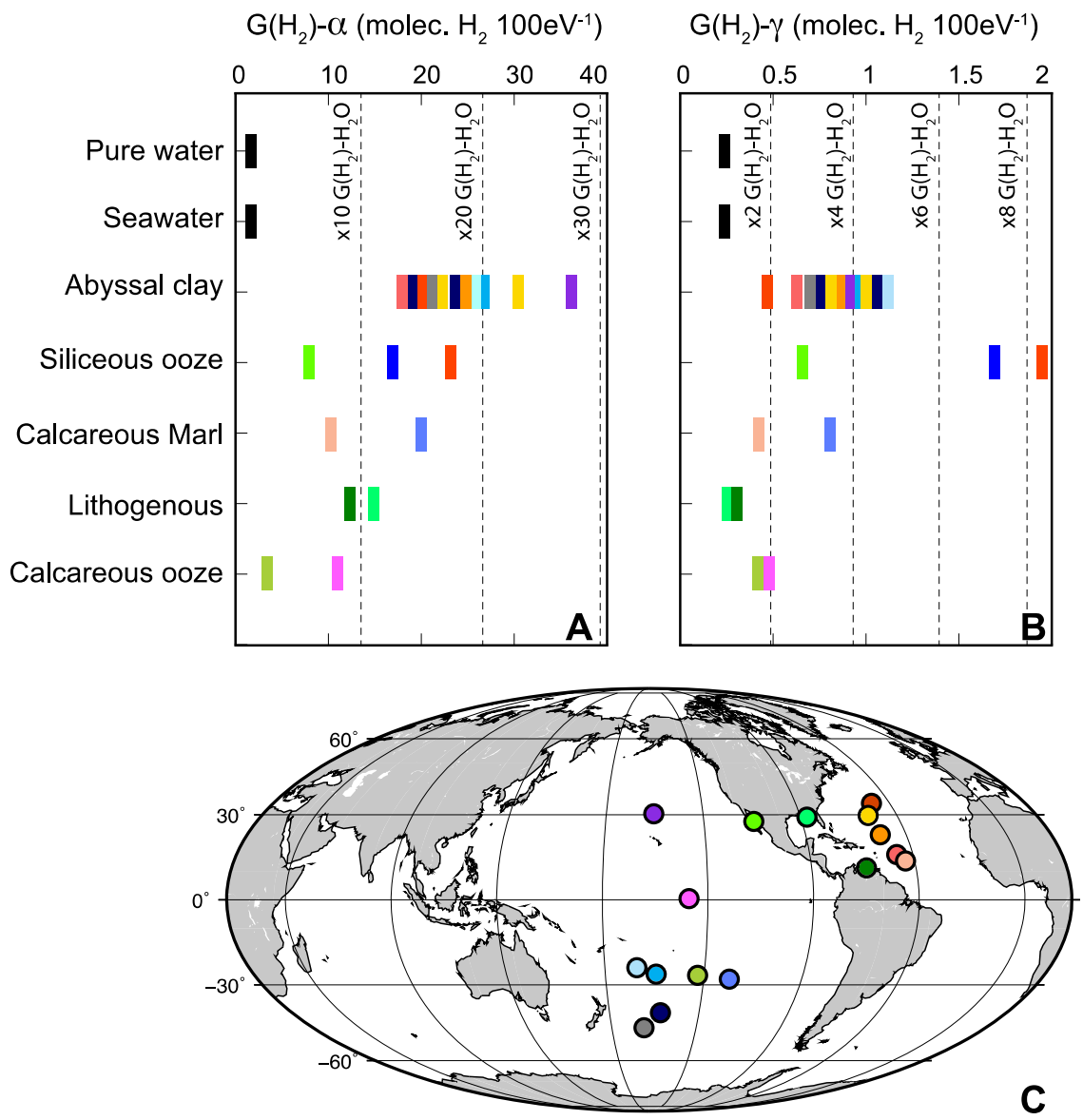

Fig. 1 Radiolytic $\mathbf{H}_{\mathbf{2}}$ catalysis by marine sediment. Experimental $\mathrm{H}_{2}$ yields for $\alpha$ irradiation $(\mathbf{A})$ and $\gamma$ irradiation (B). Reported yields are averages of a minimum of four replicate experiments. Vertical dashed lines represent multiples of production in pure water. Site locations (C) color-coded to indicate origins of samples in $\mathbf{A}$ and $\mathbf{B}$. 


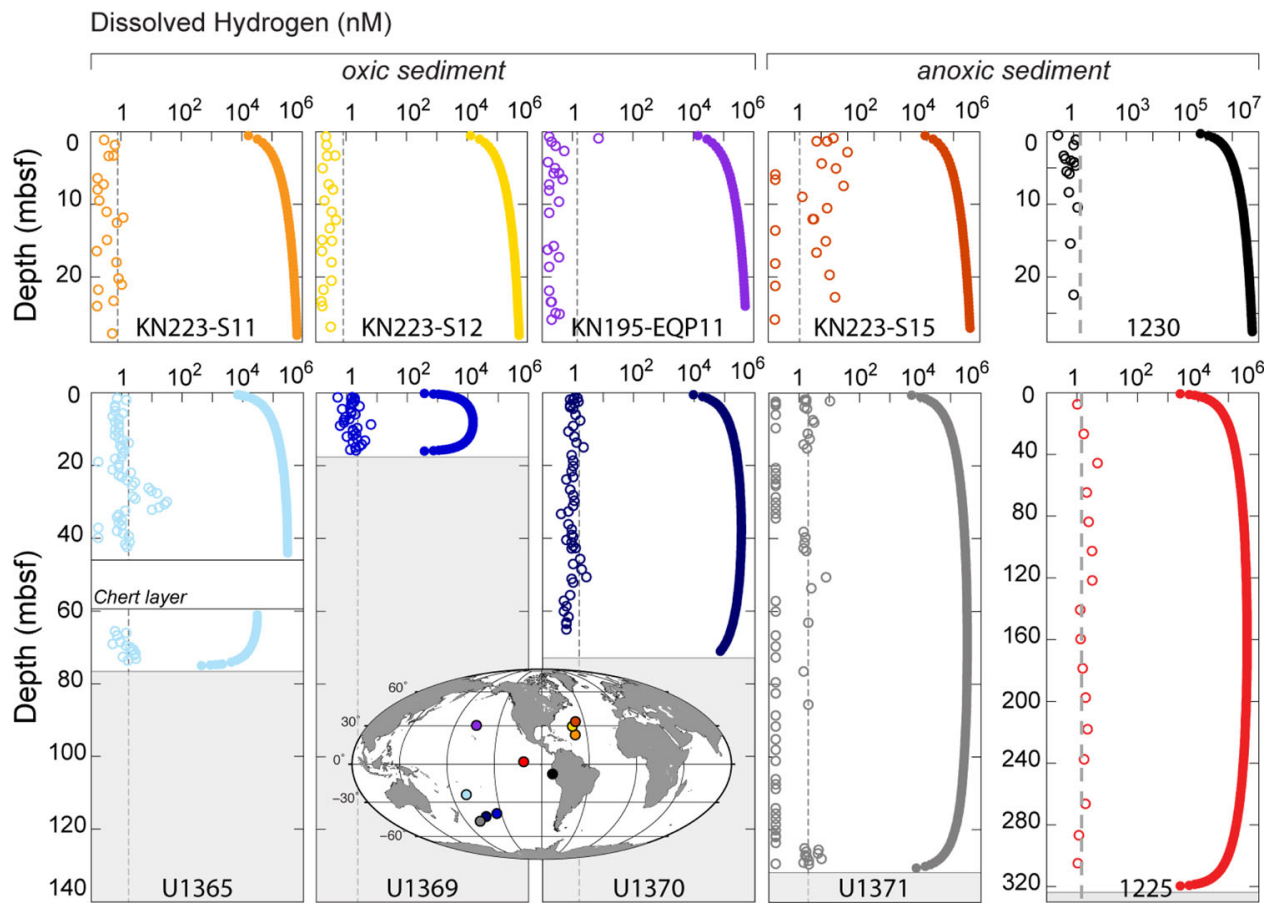

Fig. 2 Sedimentary profiles of dissolved $\mathbf{H}_{\mathbf{2}}$ concentrations. Dissolved $\mathrm{H}_{2}$ concentration profiles for North Pacific Site KN195-EQP11, South Pacific IODP Sites U1365, U1369, U1370, and U1371, North Atlantic Sites KN223-11, KN223-12 and KN223-15, Equatorial Pacific ODP Site 1225, and Peru Trench ODP Site 1230. Open symbols mark measured $\mathrm{H}_{2}$ concentrations. Solid symbols represent $\mathrm{H}_{2}$ concentrations expected from radiolytic $\mathrm{H}_{2}$ production and diffusion in the absence of in situ $\mathrm{H}_{2}$ consumption. Gray vertical lines mark detection limits for dissolved $\mathrm{H}_{2}$ concentration measurements. The detection limit of the applied analytical protocol was defined as the mean of the repeated procedural blank measurements plus three times their standard deviation. Symbol colors match site locations in Fig. 4.

oxide generating excitons that propagate to the oxide-water interface, where they lyse the water ${ }^{18-20}$. With excitons as the primary mechanism for transferring irradiation energy from sediment particles to particle-water interfaces ${ }^{18,19}$, factors that may cause variation in radiolytic $\mathrm{H}_{2}$ catalysis from one sediment type to another include mineral composition of the sediment (which affects band gap), particle size (which affects exciton migration distance), water adsorption form (physisorbed vs. chemisorbed), and surface density of hydroxyl groups ${ }^{20}$.

In addition to $\mathrm{H}_{2}$, water radiolysis generates diverse oxidized products in wet sediment. In pure water, production of $\mathrm{H}_{2}$ from radiolysis is stoichiometrically balanced by production of $\mathrm{H}_{2} \mathrm{O}_{2}$ $\left[2 \mathrm{H}_{2} \mathrm{O} \rightarrow \mathrm{H}_{2}+\mathrm{H}_{2} \mathrm{O}_{2}\right]^{12,21}$. In the presence of reduced chemicals, such as reduced sulfur and/or reduced iron, $\mathrm{H}_{2}$ production is balanced by production of $\mathrm{H}_{2} \mathrm{O}_{2}$ plus oxidation of iron and sulfur ${ }^{7,22} \cdot \mathrm{H}_{2} \mathrm{O}_{2}$ spontaneously decomposes to $1 / 2 \mathrm{O}_{2}+\mathrm{H}_{2} \mathrm{O}^{23}$; its rate of spontaneous decomposition is catalytically increased by common minerals ${ }^{24,25}$, and it readily oxidizes sulfide and iron ${ }^{26}$.

Many microorganisms can directly or indirectly utilize radiolytic $\mathrm{H}_{2}$ and/or oxidized radiolytic products as an electron donor and terminal electron acceptor, respectively ${ }^{3,27}$. Oxidizing power from water radiolysis both benefits and challenges microbes. Oxygen, oxidized iron, and oxidized sulfur are used as terminal electron acceptors by diverse microorganisms ${ }^{3,28,29}$ and some bacteria can use $\mathrm{H}_{2} \mathrm{O}_{2}$ directly as a terminal electron acceptor ${ }^{30}$. However, the $\mathrm{H}_{2} \mathrm{O}_{2}$, its degradation product $\mathrm{O}_{2}$, and the shortlived reactive oxygen species (ROS) that react to produce the $\mathrm{H}_{2} \mathrm{O}_{2}$, oxidized metal, and oxidized sulfur, can oxidatively stress microbes $^{31}$. Furthermore, ROS are critical for multiple biological processes (gene expression, intracellular signaling, cell defense) ${ }^{32}$. In short, subseafloor microbes need to manage these chemicals (particularly short-lived ROS) but can energetically benefit from reducing relatively stable radiolytic products (including $\mathrm{H}_{2} \mathrm{O}_{2}, \mathrm{O}_{2}$, oxidized iron, and sulfur species).

Despite continual radiolytic production throughout the sediment column, dissolved $\mathrm{H}_{2}$ concentrations are mostly below the detection limit (which ranges from 1-5 $\mathrm{nM} \mathrm{H}_{2}$ from site to site) in oxic subseafloor sediment ${ }^{33,34}$ and low to below detection $\left(1-30 \mathrm{nM} \mathrm{H}_{2}\right)$ in anoxic subseafloor sediment ${ }^{35}$ (Fig. 2). Measured in situ $\mathrm{H}_{2}$ concentrations are generally 2 to 5 orders of magnitude lower than expected from radiolytic production in the absence of $\mathrm{H}_{2}$-consuming reactions (Fig. 2). This discrepancy between measured and expected concentrations indicates that consumption of radiolytic $\mathrm{H}_{2}$ is essentially equal to its production throughout the sediment. The simplest explanation is microbial $\mathrm{H}_{2}$ oxidation at all depths, since enzymatic potential for $\mathrm{H}_{2}$ oxidation is ubiquitous in marine sediment ${ }^{36}$ and the in situ Gibbs energy of $\mathrm{H}_{2}$ oxidation is energy-yielding at the $\mathrm{H}_{2}$ detection limit throughout these sequences (Supplementary Information). Although this oxidation of radiolytic $\mathrm{H}_{2}$ contributes to gross redox activity, it does not contribute to net activity (e.g., net oxidant reduction) because water radiolysis generates oxidants in stoichiometric balance with $\mathrm{H}_{2}$.

We assess the potential contribution of water radiolysis in marine sediment to global bioenergy fluxes by quantifying global production of radiolytic $\mathrm{H}_{2}$ and radiolytic oxidants in marine sediment (Fig. 3). Our estimates of radiolytic $\mathrm{H}_{2}$ and oxidant production are based on (i) spatial integration of a previously published model of sedimentary water radiolysis ${ }^{2}$, (ii) our dataset of experimentally constrained radiolytic $\mathrm{H}_{2}$ yields for the principal marine sediment types, and (iii) the global distribution of sediment properties (details in "Methods"). Radiolytic production of $\mathrm{H}_{2}$ and oxidants per unit area varies by five orders of magnitude from site to site, depending primarily on sediment column 


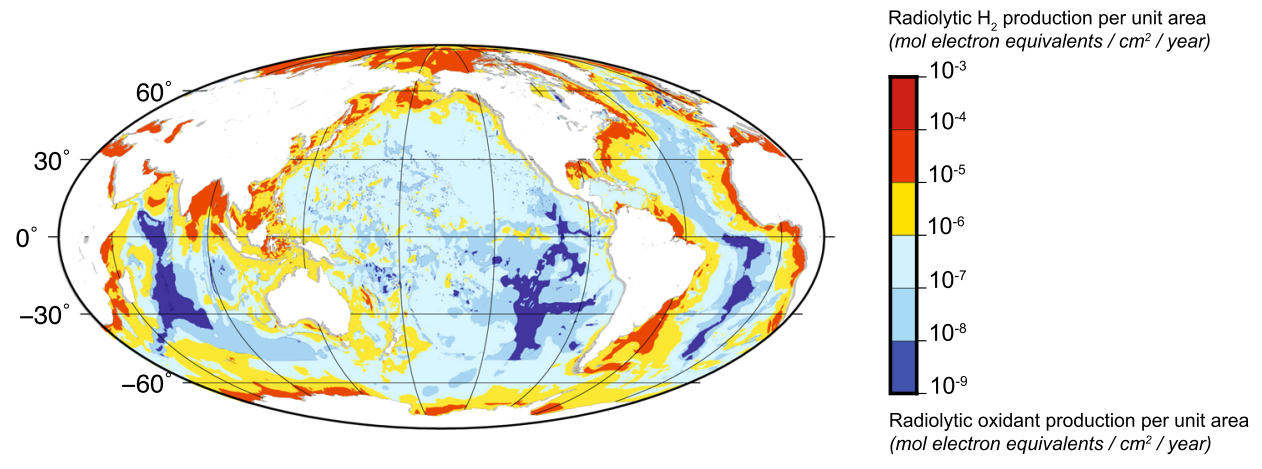

Fig. 3 Global distribution of production rates of radiolytic $\mathbf{H}_{\mathbf{2}}$ and radiolytic oxidants in marine sediment. Rates are expressed in mol electron equivalents $/ \mathrm{cm}^{2} /$ year. In electron equivalents, water radiolysis produces $\mathrm{H}_{2}$ and oxidized chemicals at equal rates. Although abyssal clay has a volumetric radiolytic production rate $\sim$ an order of magnitude higher than the volumetric rate for continental-margin sediment types, the sediment layer that blankets open-ocean regions is much thinner and consequently has much lower vertically integrated radiolytic production than the sediment of continental margins.

thickness (Fig. 3). Global production rates of radiolytic $\mathrm{H}_{2}$ and oxidants in marine sediment are $2.7 \times 10^{13} \mathrm{~mol}$ electron equivalents per year ( $\left.\mathrm{mol} \mathrm{e}^{-}{ }_{\text {eq }} \mathrm{yr}^{-1}\right)$.

These rates are significantly higher than a recent estimate of the radiolytic $\mathrm{H}_{2}$ production in Precambrian lithosphere (3.2-9.4 $\times 10^{10} \mathrm{~mol} \mathrm{e}^{-}$eq $\left.\mathrm{yr}^{-1}\right)^{13}$, which covers $72 \%$ of global continental area. Although consideration of mineral catalysis would increase the estimate for Precambrian lithosphere, it would probably not erase the difference between marine sediment and Precambrian lithosphere, because porosity is much higher and particle size is much smaller in marine sediment ${ }^{2}$ than in Precambrian lithosphere ${ }^{13}$.

Our estimated rates of radiolytic chemical production in marine sediment $\left(2.7 \times 10^{13} \mathrm{~mol} \mathrm{e}^{-}\right.$eq $\left.\mathrm{yr}^{-1}\right)$ are almost two orders of magnitude lower than the flux of organic matter (organic carbon and organic nitrogen) to the seafloor $\left(\sim 1 \times 10^{15} \mathrm{~mol} \mathrm{e}^{-} \text {eq } \mathrm{yr}^{-1}\right)^{27}$ and roughly an order of magnitude lower than the burial rate of organic matter in marine sediment $\left(0.7-3.4 \times 10^{14} \mathrm{~mol} \mathrm{e}^{-} \mathrm{eq}^{-1}\right)^{27}$. At steady state, the rate of organic consumption in marine sediment is approximated by the difference between the organic flux to the seafloor and the organic burial rate. Based on this difference, global rates of radiolytic $\mathrm{H}_{2}$ production and radiolytic electron acceptor production in marine sediment are only 1-2\% of global organic consumption in marine sediment (in electron equivalents). However, most organic consumption in marine sediment occurs at the seafloor and organic consumption rate generally decreases exponentially with sediment depth ${ }^{27}$. In contrast, production of radiolytic $\mathrm{H}_{2}$ and radiolytic oxidants is relatively constant throughout the sediment column and not focused near the seafloor.

We assess the potential importance of radiolytic products as an energy source for oxic subseafloor sedimentary ecosystems, by comparing production rates of radiolytic chemicals to net $\mathrm{O}_{2}$ reduction rates at nine sites with oxic subseafloor sediment, where organic matter concentrations are low but electron acceptors are abundant ${ }^{33}$. Redfield stoichiometry of dissolved $\mathrm{NO}_{3}{ }^{-}$to $\mathrm{O}_{2}$ indicates that net $\mathrm{O}_{2}$ consumption in these sequences is almost entirely due to organic oxidation ${ }^{33}$. In sediment deposited during the last few million years, the ratio of radiolytic $\mathrm{H}_{2}$ production to net $\mathrm{O}_{2}$ consumption is generally less than 1 (Fig. $4 \mathrm{~A}$ ), indicating that microbial respiration is primarily based on oxidation of organic matter. In older sediment, this ratio is generally greater than 1 , implying that radiolytic $\mathrm{H}_{2}$ is the primary electron donor (Fig. 4A). To the extent that oxidation of reduced metals in the sediment [e.g. $\mathrm{Mn}(\mathrm{II}), \mathrm{Fe}(\mathrm{II})$ ] also contributes to net $\mathrm{O}_{2}$ consumption, this ratio overestimates the importance of organic matter as an electron donor relative to radiolytic $\mathrm{H}_{2}$.
To evaluate the potential role of radiolytic products for sustaining subseafloor communities in anoxic sediment, we compare radiolytic production rates to dissolved inorganic carbon (DIC) production rates for seven sites from the Pacific Ocean and Bering Sea (Fig. 4B). DIC is the primary oxidized product of organic-fueled catabolism. As with oxic sediment, in anoxic sediment younger than a few $\mathrm{Ma}$, this ratio is generally less than 1.0 , indicating that organic matter is the primary electron donor. However, the ratio is generally at or above above 1 in older anoxic sediment (Fig. 4B).

Collectively, these findings suggest that radiolytic $\mathrm{H}_{2}$ is the primary electron donor in marine sediment older than a few Ma. Given the stoichiometry of water radiolysis ${ }^{12}$, these results also suggest that radiolysis is the primary source of electron acceptors in marine sediment older than a few Ma (Fig. 4A, B). This continuous release of oxidants through sediment-catalyzed water radiolysis may sustain diverse redox processes in anoxic sediment, such as (i) $\mathrm{NO}_{3}{ }^{-}$reduction inferred from transcriptomic signatures ${ }^{37}$ and (ii) $\mathrm{SO}_{4}{ }^{2-}$ reduction inferred from radiotracer incubations ${ }^{38}$ of samples taken from sediment deep beneath the last subseafloor occurrences of measurable dissolved $\mathrm{NO}_{3}{ }^{-}$and $\mathrm{SO}_{4}{ }^{2-}$. Decomposition of radiolytic $\mathrm{H}_{2} \mathrm{O}_{2}$ to $\mathrm{O}_{2}$ is also consistent with most bacterial isolates from anoxic subseafloor sediment being facultative aerobes ${ }^{39}$. Comparison to continental data ${ }^{13,16}$ indicates that subseafloor sedimentary life constitutes one of Earth's largest radiolysis-supported biomes.

This study reveals the importance of abundant geological materials as catalysts of radiolytic chemical production. Explicit recognition of this catalytic effect is necessary to constrain habitable zones within subsurface environments on Earth and other planetary bodies.

Although modern marine sediment typically contains biogenic components (carbonate and/or opal microfossils, fish teeth, etc.), its mineral composition directly overlaps with the mineral composition of early Earth and other planetary bodies. The known catalytic minerals abundant in marine sediment (zeolites and calcite) are inferred to have existed on early Earth ${ }^{40}$. Zeolites and other minerals dominant in marine sediment (smectite, chlorite, opaline silica) are present on Mars ${ }^{41-43}$.

On modern Earth, naturally catalyzed radiolytic products appear to provide the dominant fuel for microbial activity in marine sediment older than a few Ma. Where catalytic materials were present, radiolytic products may also have been significant for pre-photosynthetic life on early Earth and where water permeates similarly catalytic material on other planets and moons, such as the subsurface environments of Mars ${ }^{42}$, Europa, or Enceladus, life may similarly be sustained today. 
A Ratios of radiolytic $\mathrm{H}_{2}$ production to net $\mathrm{O}_{2}$ reduction (in electron equivalents)

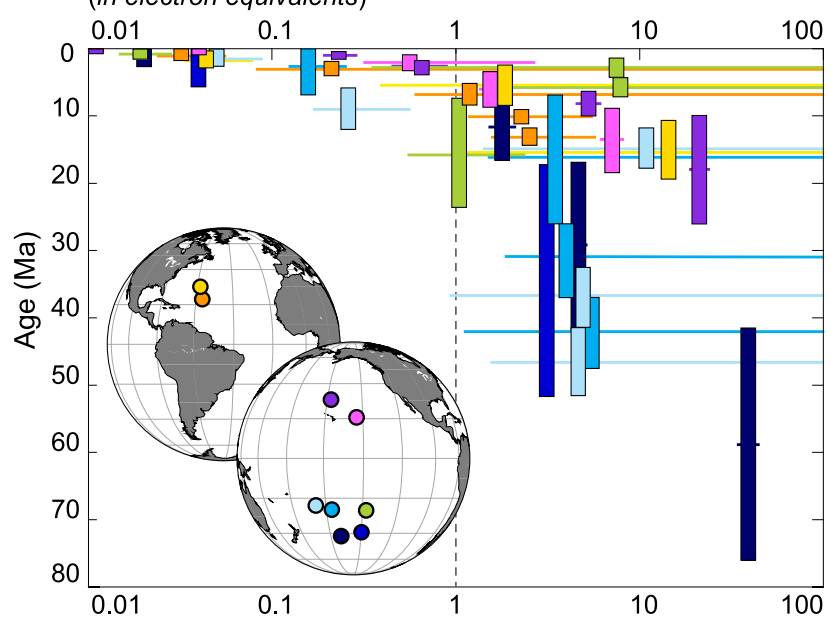

Ratios of radiolytic oxidant production to net $\mathrm{O}_{2}$ reduction (in electron equivalents)

B Ratios of radiolytic $\mathrm{H}_{2}$ production to net DIC production (in electron equivalents)

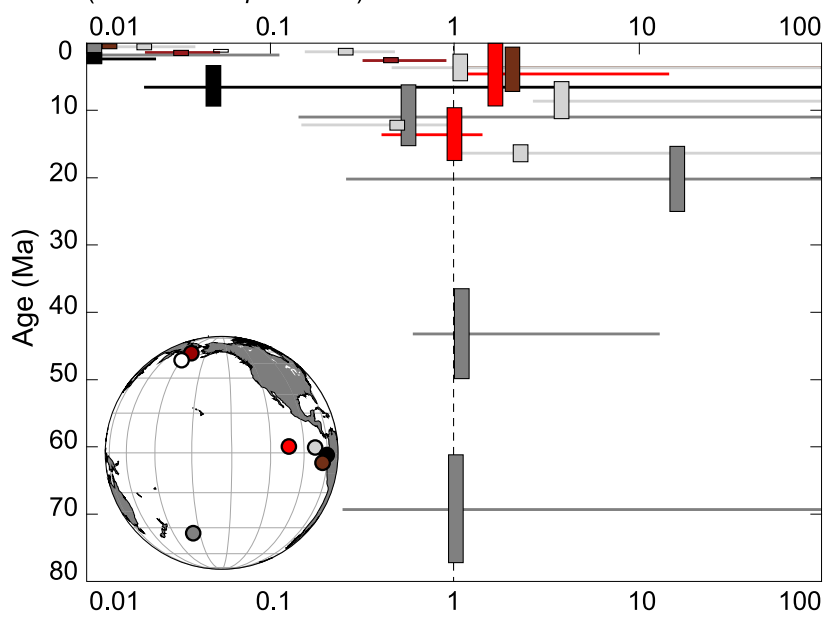

Ratios of radiolytic oxidant production to net DIC production (in electron equivalents)

Fig. 4 Metabolic contribution of radiolytic products in marine sediment. A Ratios of (i) radiolytic $\mathrm{H}_{2}$ production to net $\mathrm{O}_{2}$ reduction and (ii) radiolytic oxidant production to net $\mathrm{O}_{2}$ reduction, plotted against sediment age for sites with oxic deep subseafloor sediment. Horizontal lines represent one standard deviation of the ratio of radiolytic $\mathrm{H}_{2}$ production to net $\mathrm{O}_{2}$ reduction. B Ratios of (i) radiolytic $\mathrm{H}_{2}$ production to net dissolved inorganic carbon (DIC) production and (ii) radiolytic oxidant production to net DIC production for sites with anoxic deep subseafloor sediment. Horizontal lines represent one standard deviation of the ratio of radiolytic $\mathrm{H}_{2}$ production to net DIC production. The transition from ratios below 1 (organic oxidation dominance) in young sediment to ratios above 1 (radiolytic dominance) in older sediment results from large decreases in organic oxidation rates with increasing sediment age; radiolytic production of $\mathrm{H}_{2}$ and oxidants is relatively constant with sediment age, assuming no major changes in sediment composition.

\section{Methods}

Radiation experiments. We experimentally quantified radiolytic hydrogen $\left(\mathrm{H}_{2}\right)$ production in (i) pure water, (ii) seawater, and (iii) seawater-saturated sediment We irradiated these materials with $\alpha$ - or $\gamma$-radiation for fixed time intervals and then determined the concentrations of $\mathrm{H}_{2}$ produced. Sediment samples were slurried with natural seawater to achieve a slurry porosity $(\varphi)$ of $\sim 0.83$, which is the average porosity of abyssal clay in the South Pacific Gyre ${ }^{34}$. The seawater source is described below. To avoid microbiological uptake of radiolytic $\mathrm{H}_{2}$ during the course of the experiment, seawater and marine sediment slurries were pre-treated with $\mathrm{HgCl}_{2}$ ( $0.05 \%$ solution) or $\mathrm{NaN}_{3}(0.1 \% \mathrm{wt} / \mathrm{vol})$. To ensure that addition of these chemicals did not impact radiolytic $\mathrm{H}_{2}$ yields, irradiation experiments with pure water plus $\mathrm{HgCl}_{2}$ or $\mathrm{NaN}_{3}$ were also conducted. $\mathrm{HgCl}_{2}$ or $\mathrm{NaN}_{3}$ addition had no statistically significant impact on $\mathrm{H}_{2}$ yields $s^{5,6,10}$.

Experimental samples were irradiated in $250 \mathrm{~mL}$ borosilicate vials. A solid-angle ${ }^{137} \mathrm{Cs}$ source (beam energy of $0.67 \mathrm{MeV}$ ) was used for the $\gamma$-irradiation experiments at the Rhode Island Nuclear Science Center (RINSC). The calculated dose rate for sediment slurries was $2.19 \mathrm{E}-02 \mathrm{~Gy} \mathrm{~h}^{-1}$ accounting for the (i) source activity, (ii) distance between the source and the samples, (iii) sample vial geometry, and (iv) attenuation coefficient of $\gamma$-radiation through air, borosilicate, and sediment slurry. ${ }^{210} \mathrm{Po}\left(5.3 \mathrm{MeV}\right.$ decay $\left.{ }^{-1}\right)$-plated silver strips with total activities of $250 \mu \mathrm{Ci}$ were used for the $\alpha$-irradiation experiments. For $\alpha$-irradiation of each sediment slurry, a ${ }^{210} \mathrm{Po}$-plated strip was placed inside the borosilicate vial and immersed in the slurry. Calculated total absorbed doses were $4 \mathrm{~Gy}$ and $3 \mathrm{kGy}$ for $\gamma$-irradiation and $a$-irradiation experiments, respectively.

The settling time of sediment grains in the slurries (1 week) was long compared to the time span of each experiment (tens of minutes to an hour for a-experiments, hours to days for $\gamma$-experiments). Therefore, we assumed that the suspension was homogenous during the course of each experiment.

$\mathrm{H}_{2}$ concentrations were measured by quantitative headspace analysis via gas chromatography. For headspace analysis, $30 \mathrm{~mL}$ of $\mathrm{N}_{2}$ was first injected into the sample vial. To avoid over-pressurization of the sample during injection, an equivalent amount of water was allowed to escape through a separate needle. The vials were then vigorously shaken for 5 min to concentrate the $\mathrm{H}_{2}$ into the headspace. Finally, a 500- $\mu \mathrm{L}$-headspace subsample was injected into a reduced gas analyzer (Peak Performer 1, PP1). The reduced gas analyzer was calibrated using a 1077 ppmv $\mathrm{H}_{2}$ primary standard (Scott-Marrin, Inc.). A gas mixer was used to dilute the $\mathrm{H}_{2}$ standard with $\mathrm{N}_{2}$ gas to obtain various $\mathrm{H}_{2}$ concentrations and produce a five-point linear calibration curve $(0.7,2,5,20$, and $45 \mathrm{ppm}) . \mathrm{H}_{2}$ concentrations of procedural blanks consisting of sample vials filled with nonirradiated deionized 18-M $\Omega$ water were also determined. The concentration detection limit obtained using this protocol was $0.8-1 \mathrm{nM} \mathrm{H}_{2}$. Relative error was less than $5 \%$. Radiation experiments were performed at a minimum in triplicate.

Sample selection and experimental radiolytic $\mathbf{H}_{\mathbf{2}}$ yields, $\mathbf{G}\left(\mathbf{H}_{\mathbf{2}}\right)$. Millipore Milli$\mathrm{Q}$ system water was used for our pure-water experiments. For seawater experiments, we used bottom water collected in the Hudson Canyon (water depth, $2136 \mathrm{~m}$ ) by RV Endeavor expedition EN534. Salinity of North Atlantic bottom water in the vicinity of the Hudson Canyon $\left(34.96 \mathrm{~g} \mathrm{~kg}^{-1}\right)$ is similar to that of mean open-ocean bottom water $\left(34.70 \mathrm{~g} \mathrm{~kg}^{-1}\right)^{44,45}$

The 20 sediment samples used for the experiments were collected by scientific coring expeditions in three ocean basins (expedition KN223 to the North Atlantic ${ }^{46}$, expedition KN195-3 to the Equatorial and North Pacific ${ }^{47}$, International Ocean Discovery Program (IODP) Expedition 329 to the South Pacific Gyre ${ }^{34}$, MONA expedition to the Guaymas Basin ${ }^{48}$, expedition EN32 to the Gulf of Mexico ${ }^{49}$, and expedition EN20 to the Venezuela Basin ${ }^{50}$ ). To capture the dominant sediment types present in the global ocean, we selected samples typical of five common sediment types [abyssal clay (11 samples), nannofossil-bearing clay or calcareous marl (2 samples), clay-bearing diatom ooze (3 samples), calcareous ooze ( 2 samples), and lithogenous sediment ( 2 samples)]. The locations, lithological descriptions, and mineral compositions of the samples are given in Supplementary Tables 1,2, 3, and Supplementary Fig. 1. Additional chemical and physical descriptions of the sediment samples used in the radiation experiments can be found in the expedition reports for the expeditions on which the samples were collected 34,46

Energy-normalized radiolytic $\mathrm{H}_{2}$ yields are commonly expressed as $\mathrm{G}\left(\mathrm{H}_{2}\right)$ values (molecules $\mathrm{H}_{2}$ per $100 \mathrm{eV}$ absorbed) ${ }^{1}$. As shown in Supplementary Fig. 2, for all irradiated samples (pure water, seawater, and marine sediment slurries), $\mathrm{H}_{2}$ production increased linearly with absorbed $\alpha$ - and $\gamma$-ray-dose. We calculated $\mathrm{G}\left(\mathrm{H}_{2}\right)$-values for each sample and radiation type $(\alpha$ or $\gamma)$ as the slope of the leastsquare regression line of radiolytic $\mathrm{H}_{2}$ concentration versus absorbed dose (Supplementary Fig. 2). The error on the yields is less than $10 \%$ for each sample. $\mathrm{G}\left(\mathrm{H}_{2}\right)$-values for each sample and radiation type $(\alpha$ or $\gamma)$ are reported in Supplementary Table 3.

Although radiolytic $\mathrm{OH} \bullet$ is known to react with dissolved organic matter ${ }^{51}$, total organic content does not appear to significantly impact radiolytic $\mathrm{H}_{2}$ production, since the most organic-rich sediment (e.g., Guaymas Basin and Gulf of Mexico sediment) did not yield particularly high $\mathrm{H}_{2}$ (Supplementary Table 3).

Calculated radiolytic production rates of $\mathbf{H}_{2}$ and oxidants in the cored sediment of individual sites. We calculated radiolytic $\mathrm{H}_{2}$ production rates $\left(P_{\mathrm{H} 2}\right.$, in molecules $\mathrm{H}_{2} \mathrm{~cm}^{-3} \mathrm{yr}^{-1}$ ) for the cored sediment column at nine sites with oxic subseafloor sediment in the North Pacific, South Pacific, and North Atlantic; and seven sites with anoxic subseafloor sediment in the Bering Sea, South Pacific, Equatorial Pacific, and Peru Margin (see Supplementary Fig. 3 for site locations). For these calculations, we used the following equation from Blair et al. ${ }^{2}$ :

$$
P_{\mathrm{H}_{2}}=\sum A_{\mathrm{m}, i} \rho(1-\varphi) E_{i} \mathrm{G}\left(\mathrm{H}_{2}\right)_{i}
$$

where $i$ is alpha, beta, or gamma radiation; $A_{\mathrm{m}}$ is radioactivity per mass solid; $\varphi$ is porosity; $\rho$ is density solid; $E_{i}$ is decay energy; and $\mathrm{G}\left(\mathrm{H}_{2}\right)_{i}$ is radiolytic yield. 
We calculated radiolytic oxidant production rates for these sediment columns from the $\mathrm{H}_{2}$ production rates. Because $\mathrm{H}_{2}$ production and oxidant production are stochiometrically balanced in water radiolysis $\left[2 \mathrm{H}_{2} \mathrm{O} \rightarrow \mathrm{H}_{2}+\mathrm{H}_{2} \mathrm{O}_{2}\right]$, the calculated radiolytic $\mathrm{H}_{2}$ production rates (in electron equivalents) are equal to radiolytic oxidant production rates (in electron equivalents).

The in situ $\gamma$-and $\alpha$-radiation dosages in marine sediment are, respectively, 13 and 15 orders of magnitude lower than the dosage used in our experiments. Because the measured $\mathrm{G}\left(\mathrm{H}_{2}\right)$ for pure water in our $\gamma$-irradiation experiment (dose rate $=2.19 \mathrm{E}-02 \mathrm{~Gy} \mathrm{~h}^{-1}$ ) is statistically indistinguishable from previously published $\mathrm{G}\left(\mathrm{H}_{2}\right)$ values at much higher dose rates (ca. $\left.1.00 \mathrm{E}+3 \mathrm{~Gy} \mathrm{~h}^{-1}\right)^{5}$, we infer that the $\gamma$-irradiation $\mathrm{G}\left(\mathrm{H}_{2}\right)$ value is constant with dose rate over five orders of magnitude. Similarly, our experimental pure water $\mathrm{H}_{2}$ yields following $\alpha$-particle irradiation from a ${ }^{210} \mathrm{Po}$-source (dose rate of $2.55 \mathrm{E}+03 \mathrm{~Gy} \mathrm{~h}^{-1}$ ) are indistinguishable from the yield obtained by Crumière et al. ${ }^{6}\left[\mathrm{G}\left(\mathrm{H}_{2}\right)=1.30 \pm 0.13\right]$ for air-saturated deionized water exposed to a cyclotron-generated $\mathrm{He}^{2+}$ particle beam at higher dose rate (dose rate $1.62 \mathrm{E}+05 \mathrm{~Gy} \mathrm{~h}^{-1}$ ). The close similarity in $\mathrm{H}_{2}$ yields obtained in both experiments implies that (i) radiolytic $\mathrm{H}_{2}$ yield from $\alpha$-particle irradiation is identical to that from cyclotron-generated $\mathrm{He}^{2+}$ particle irradiation, and (ii) this yield is constant over a two-orders-of-magnitude range dose rate. Therefore, we use our experimentally determined $\alpha$ - and $\gamma$-irradiation $\mathrm{G}\left(\mathrm{H}_{2}\right)$ values for the low radiation dose rate found in the subseafloor. Because the $\mathrm{G}\left(\mathrm{H}_{2}\right)$ of $\beta$ irradiation has not been experimentally determined for water-saturated materials, we assume that the $\mathrm{G}\left(\mathrm{H}_{2}\right)$ of $\beta$-radiation matches the $\mathrm{G}\left(\mathrm{H}_{2}\right)$ of $\gamma$-radiation for the same sediment types. In pure water, their $\mathrm{G}\left(\mathrm{H}_{2}\right)$ values differ by only $17 \%{ }^{1}$. Because $\beta$ radiation, on average, contributes only $11 \%$ of the total radiolytic $\mathrm{H}_{2}$ production from the $\mathrm{U}$, Th series and $\mathrm{K}$ decay in marine sediment, these estimates of total $\mathrm{H}_{2}$ production differ by only $2-5 \%$ relative to estimates where the $G\left(\mathrm{H}_{2}\right)$ of $\beta$ radiation is assumed equal to that for pure water or for a radiation of the same sediment types.

To calculate $\mathrm{H}_{2}$ production rates for the entire sediment column at seven South Pacific sites and two North Atlantic sites, we measured downcore sediment profiles of U, Th, and K (i) 187 sediment samples from IODP Expedition 329 Sites U1365, U1366, U1367, U1368, U1369, U1370, and U1371 34,52 , and (ii) 40 samples from KN223 expedition Sites 11 and 12 (ref. ${ }^{46}$ ). Total U and Th (ppm) and $\mathrm{K}_{2} \mathrm{O}$ (wt\%) for these sites are reported in the EarthChem SedDB data repository. We measured $\mathrm{U}$, Th, and $\mathrm{K}$ abundances using standard atomic emission and mass spectrometry techniques (i.e. ICP-ES and ICP-MS) in the Analytical Geochemistry Facilities at Boston University. Sample preparation, analytical protocol, and data are reported in Dunlea et al..$^{52}$. The precision for each element is $\sim 2 \%$ of the measured value, based on three separate digestions of a homogenized in-house standard of deep-sea sediment.

To calculate $\mathrm{H}_{2}$ production rates for the sediment columns at North Pacific coring Sites EQP10 and EQP11 (ref. ${ }^{47}$ ), we used radioactive element content data from Kyte et al. ${ }^{53}$, who measured chemical concentrations at high resolution in bulk sediment in core LL44-GPC3. Because Site EQP11 was cored at the same location as LL44-GPC3 (ref. ${ }^{53}$ ) and the sediment retrieved at all three sites is homogeneous abyssal clay, we assume the radioactive element abundances measured in core LL44-GPC3 to be representative of Sites EQP10 and EQP11 (ref. ${ }^{47}$ ). Calculated radiolytic $\mathrm{H}_{2}$ production rates for South Pacific sites are listed in Supplementary Table 4 and for North Atlantic and North Pacific sites in Supplementary Table 5 .

For Bering Sea Sites U1343 and U1345 (ref. ${ }^{54}$ ), sedimentary U, Th, and K content measurements are unavailable. Since sediment recovered at these two sites is primarily siliciclastic with a varying amount of diatom-rich clay, we use $U, T h$, and $\mathrm{K}$ concentration values reported for upper continental crust by $\mathrm{Li}$ and Schoonmaker for these Bering Sea sites ${ }^{55}$. Finally, we calculate downhole radiolytic $\mathrm{H}_{2}$ production rates for ODP Leg 201 Sites 1225, 1226, 1227, and 1230 (ref. ${ }^{35}$ ). Sediment compositions for these sites include nannofossil-rich calcareous ooze (Site 1225), alternation of nannofossil (calcareous) ooze and diatom ooze (Site 1226), and siliciclastic with diatom-rich clay intervals (Sites 1227 and 1230). Because sedimentary $\mathrm{U}$, Th, and $\mathrm{K}$ measurements are not available for Leg 201 sites, we used average U, Th, and $\mathrm{K}$ concentration values measured in North Atlantic $^{46}$ and South Pacific Sites ${ }^{34,52}$ with corresponding lithologies.

We use isotopic abundance values reported in Erlank et al. ${ }^{56}$ to calculate the abundance of ${ }^{238} \mathrm{U},{ }^{235} \mathrm{U},{ }^{232} \mathrm{Th}$, and ${ }^{40} \mathrm{~K}$ from the measured ICP-MS values of total $\mathrm{U}, \mathrm{Th}$, and $\mathrm{K}$ concentration. We then converted radionuclide concentrations to activities using Avogadro's number and each isotope's decay constant ${ }^{2}$. We refer to Blair et al. for a detailed explanation of activities and radiolytic yield calculations ${ }^{2}$.

\section{Calculation of global radiolytic $\mathbf{H}_{\mathbf{2}}$ and oxidant production rates in marine} sediment. We calculated global radiolytic $\mathrm{H}_{2}$ production in ocean sediment by applying Eq. (1) (ref. ${ }^{2}$ ) globally. As with the rates at individual sites, we calculated global radiolytic oxidant production (in electron equivalents) from global $\mathrm{H}_{2}$ production and the stochiometry of water radiolysis $\left[2 \mathrm{H}_{2} \mathrm{O} \rightarrow \mathrm{H}_{2}+\mathrm{H}_{2} \mathrm{O}_{2}\right]$.

Our global radiolytic $\mathrm{H}_{2}$ production calculation spatially integrates calculations of sedimentary porewater radiolysis rates that are based on (i) our experimentally constrained radiolytic $\mathrm{H}_{2}$ yields for the principal marine sediment types, (ii) measured radioactive element content of sediment cores in three ocean basins (North Atlantic ${ }^{46}$, North Pacific ${ }^{53}$, and South Pacific ${ }^{34,52}$ ), and (iii) global distributions of sediment lithology ${ }^{57}$, sediment porosity ${ }^{58}$, and sediment column length ${ }^{59,60}$

To generate the global map of radiolytic $\mathrm{H}_{2}$ production, we created global maps of seafloor $\mathrm{U}$, Th, and $\mathrm{K}$ concentrations, density, $\mathrm{G}\left(\mathrm{H}_{2}\right)-\alpha$ values, and $\mathrm{G}\left(\mathrm{H}_{2}\right)-\gamma-$ and $\beta$ by assigning each grid cell in our compiled seafloor lithology map

(Supplementary Fig. 4) its lithology-specific set of input variables (Supplementary Table 6). Because our model assumes that lithology is constant with depth, $\mathrm{U}, \mathrm{Th}$ and $\mathrm{K}$ content, grain density, and $\mathrm{G}\left(\mathrm{H}_{2}\right)$-values are constant with depth.

The $\mathrm{G}\left(\mathrm{H}_{2}\right)$-values ( $\alpha, \beta$, and $\gamma$ radiation), radioactive element content (sedimentary $\mathrm{U}$, Th, and $\mathrm{K}$ concentration), density, porosity, and sediment thickness are determined as follows.

Radiolytic yield $\left[\mathbf{G}\left(\mathbf{H}_{\mathbf{2}}\right)\right]$ for $\boldsymbol{\alpha}, \boldsymbol{\beta}-\boldsymbol{\delta}-\boldsymbol{\gamma}$ radiation. Radiolytic yields for the main seafloor lithologies are obtained by averaging experimentally derived yields for the respective lithologies (Supplementary Table 6). We assume that $\mathrm{G}\left(\mathrm{H}_{2}\right)-\beta$ values equal $\mathrm{G}\left(\mathrm{H}_{2}\right)-\gamma$ values.

Sediment lithology. For these calculations of radiolytic chemical production, we generally used seafloor lithologies and assumed that sediment type is constant with sediment depth. For seafloor lithology, the geographic database of global bottom sediment type ${ }^{57}$ was compiled into five lithologic categories: abyssal clay, calcareous ooze, siliceous ooze, calcareous marl, and lithogenous (Supplementary Fig. 4). Some areas of the seafloor are not described in the database $\mathrm{e}^{57}$. These include (i) highlatitude regions (as the seafloor lithology database extends from $70^{\circ} \mathrm{N}$ to $\left.50^{\circ} \mathrm{S}\right)^{57}$ and (ii) some discrete areas located along continental margins (e.g., Mediterranean Sea, Timor Sea, South China Sea, Supplementary Fig. 4). We used other data sources to identify seafloor lithologies for these regions. We added an opal belt (siliceous ooze) in the Southern Ocean between $57^{\circ} \mathrm{S}$ and $66^{\circ} \mathrm{S}^{61,62}$. The geographic extent of this opal belt was based on DeMaster ${ }^{62}$ and Dutkiewicz et al. ${ }^{61}$. We defined the areas of the seafloor from $50^{\circ} \mathrm{S}$ to $57^{\circ} \mathrm{S}$, from $66^{\circ} \mathrm{S}$ to $90^{\circ} \mathrm{S}$, and in the Arctic Ocean as mostly composed of lithogenous material, based on (i) drillsite lithologies in the Southern Ocean [ODP: Site 695 (ref. ${ }^{63}$ ), Site 694 (ref. ${ }^{63}$ ), Site 1165 (ref. ${ }^{64}$ ), Site 739 (ref. ${ }^{65}$ )], the Bering Sea and Arctic Ocean [International Ocean Discovery Program (IODP): Sites U1343 and U1345 (ref. ${ }^{54}$ ), Site M0002 (ref. ${ }^{66}$ ), ODP: Site 910 (ref. ${ }^{67}$ ), Site 645 (ref. ${ }^{68}$ )] and between $50^{\circ} \mathrm{S}$ and $57^{\circ} \mathrm{S}$ [Deep Sea Drilling Project (DSDP): Site 326 (ref. ${ }^{69}$ ), Ocean Drilling Program (ODP): Site 1138 (ref. ${ }^{70}$ ), Site 1121 (ref. ${ }^{71}$ )], and Dutkiewicz et al. ${ }^{61}$.

In the North and South Atlantic, sediment type can be very different at depth than at the seafloor. For these regions, we departed from our assumption that sediment lithology is the same at depth as at the seafloor. Subseafloor lithologies at ODP Sites [1063 (ref. ${ }^{72}$ ), 951 (ref. ${ }^{73}$ ), 925 (ref. ${ }^{74}$ ), and 662 (ref. ${ }^{75}$ )] and IODP Sites [U1403 (ref. ${ }^{76}$ ) and U1312 (ref. ${ }^{77}$ )] indicate that sediment in the Atlantic Ocean basin is generally $30-90 \%$ biogenic carbonate content and detrital clay ${ }^{78}$, even where the seafloor lithology is abyssal clay ${ }^{57}$. Therefore, regions in the Atlantic Ocean described as abyssal clay in the seafloor lithology database ${ }^{57}$ were characterized as calcareous marl for our calculations (Supplementary Fig. 4). Because abyssal clay catalyzes radiolytic $\mathrm{H}_{2}$ production at a higher rate than calcareous marl, this characterization may underestimate production of radiolytic $\mathrm{H}_{2}$ and radiolytic oxidants in these Atlantic regions.

Radioactive element content. For four of the five lithologic types in our global maps (abyssal clay, siliceous ooze, calcareous ooze, and calcareous marl), we average $\mathrm{U}$, Th, and $\mathrm{K}$ concentrations from sites in the North Atlantic ${ }^{46}$, North Pacific ${ }^{53}$, and South Pacific ${ }^{34,52}$. The average $\mathrm{U}, \mathrm{Th}$, and $\mathrm{K}$ concentration values are consistent with data reported in $\mathrm{Li}$ and Schoonmaker ${ }^{55}$ for the characteristic $\mathrm{U}, \mathrm{Th}$, and $\mathrm{K}$ content found in abyssal clay and calcareous ooze. For lithogenous sediment, we use $\mathrm{U}, \mathrm{Th}$, and $\mathrm{K}$ concentration values reported for upper continental crust by $\mathrm{Li}$ and Schoonmaker ${ }^{55}$. Lithology-specific radioactive element values are given in Supplementary Table 6 and used to calculate $A_{\mathrm{m}, i}$ in Eq. (1).

Density. Characteristic density values for calcite, quartz, terrigenous clay, and opal-rich sediment were extracted from the Proceedings of the Integrated Ocean Drilling Program Volume 320/321 and are assigned to calcareous ooze, lithogenous sediment, abyssal clay, and siliceous ooze, respectively ${ }^{79}$.

Global porosity. For global porosity, we use a seafloor porosity data set by Martin et al. ${ }^{58}$ and accounted for sediment compaction with depth by using separate sediment compaction length scales for continental-shelf $(0-200 \mathrm{~m}$ water depth; $\left.c_{0}=0.5 \times 10^{-3}\right)$, continental-margin $\left(200-2500 \mathrm{~m} ; c_{0}=1.7 \times 10^{-3}\right)$, and abyssal sediment $\left(>3500 \mathrm{~m} ; c_{0}=0.85 \times 10^{-3}\right)^{80,81}$. Once the porosity was $0.1 \%$, the depth integration was halted.

Global sediment thickness. We calculated global depth-integrated radiolytic $\mathrm{H}_{2}$ production by summing the seafloor production rates over sediment depth in onemeter intervals (Fig. 3 in main text). Sediment thickness is from Whittaker et al., supplemented with Laske and Masters where needed ${ }^{82,83}$. 
Ocean depth. For porosity calculations, water depths were determined using the General Bathymetric Chart of the Oceans ${ }^{84}$, resampled to a 5 -arc minute grid, i.e. the resolution of the Naval Oceanographic Office's Bottom Sediment Type (BTS) database "Enhanced dataset"

Dissolved $\mathbf{H}_{\mathbf{2}}$ concentration profiles. $\mathrm{H}_{2}$ concentrations from South Pacific Sites U1365, U1369, U1370, and U1371, and the measurement protocol, are described in ref. ${ }^{1} . \mathrm{H}_{2}$ concentrations from North Atlantic KN223 Sites 11,12 , and 15, and North Pacific Site EQP11 were determined using the same protocol and are posted on SedDB (see "Data availability"). The detection limit for $\mathrm{H}_{2}$ ranged between 1 and $5 \mathrm{nM} \mathrm{H}_{2}$, depending on site, and is displayed as gray vertical lines in Fig. 2 of the main text. $\mathrm{H}_{2}$ concentrations for Equatorial Pacific Site 1225 and Peru Trench Site 1230 were measured by the "headspace equilibration technique", which measures steady-state $\mathrm{H}_{2}$ levels reached following laboratory incubation of the sediment samples ${ }^{85,86}$

For comparison to these measured $\mathrm{H}_{2}$ concentrations, we use diffusion-reaction calculations to quantify what in situ $\mathrm{H}_{2}$ concentrations would be in the absence of $\mathrm{H}_{2}$-consuming reactions. The results of these calculations are represented as solid circles (•) in Fig. 2 of the main text. Temporal changes in $\mathrm{H}_{2}$ concentration due to diffusive processes and radiolytic $\mathrm{H}_{2}$ production in situ are expressed by Eq. (2):

$$
\frac{\partial \mathrm{H}_{2}(x, t)}{\partial t}=\frac{D}{\varphi F} \frac{\partial^{2} \mathrm{H}_{2}(x, t)}{\partial x^{2}}+P(x)
$$

with

$D$ : the diffusion coefficient of $\mathrm{H}_{2}(\mathrm{aq})$ at in situ temperature

$\varphi$ : porosity

$F$ : formation factor

$x$ : depth

$Z$ : sediment column thickness

$\mathrm{H}_{2}$ : hydrogen concentration

$P$ : radiolytic $\mathrm{H}_{2}$ production rate

$t$ : time.

With constant radiolytic $\mathrm{H}_{2}$ production, $P(x)=P$ with depth,

and at steady-state,

$$
\frac{\partial^{2} \mathrm{H}_{2}(x)}{\partial x^{2}}=-\frac{P \varphi F}{D} .
$$

We integrate Eq. (3) over the length $x$ twice,

$$
\mathrm{H}_{2}(x)=-\frac{1}{2} \frac{P \varphi F}{D} x^{2}+A x+B
$$

where $A$ and $B$ in Eq. (4) are constants of integration. We use two boundary conditions to derive the value of these constants.

Boundary condition 1: concentration of $\mathrm{H}_{2}$ at the sediment-water interface, $x=$ 0 , is zero due to diffusive loss to the overlying water column.

Boundary condition 2: concentration of $\mathrm{H}_{2}$ at the basement-sediment-water

interface, $x=Z$, is zero due to diffusive loss to the underlying basement.

With these boundary conditions, $A=\frac{1}{2} \frac{P \varphi F}{D} Z$ and $B=0$ and

$$
\mathrm{H}_{2}(x)=\frac{1}{2} \frac{P \varphi F}{D}\left(x Z-x^{2}\right) .
$$

In cases where we expect radiolytic $\mathrm{H}_{2}$ production rates to significantly vary with depth due to changes in lithology, we adapted the boundary conditions and applied a two-layer diffusion model to account for this variation.

Calculation of Gibbs Energies for the Knallgas reaction. For $\mathrm{H}_{2}$ concentrations above the detection limits at South Pacific IODP Expedition 329 sites (Supplementary Fig. 5 $)^{34}$, we quantified in situ Gibbs energies $\left(\Delta G_{\mathrm{r}}\right)$ of the Knallgas reaction $\left(\mathrm{H}_{2}+1 / 2 \mathrm{O}_{2} \rightarrow \mathrm{H}_{2} \mathrm{O}\right)$. In situ $\Delta G_{\mathrm{r}}$ values depend on pressure $(P)$, temperature $(T)$, ionic strength, and chemical concentrations, all of which are explicitly accounted for in our calculations:

$$
\Delta G_{\mathrm{r}}=\Delta G_{\mathrm{r}}^{\circ}(T, P)+2.3 R T \log _{10} Q
$$

where:

$\Delta G_{\mathrm{r}}$ : in situ Gibbs energy of reaction $\left(\mathrm{kJ} \mathrm{mol} \mathrm{H}_{2}{ }^{-1}\right)$

$\Delta G_{\mathrm{r}}^{\circ}(T, P)$ : Gibbs energy of reaction under in situ $T$ and $P$ conditions $\left(\mathrm{kJ} \mathrm{mol} \mathrm{H} \mathrm{H}^{-1}\right)$

$R$ : gas constant $\left(8.314 \mathrm{~kJ}^{-1} \mathrm{~mol} \mathrm{~K}^{-1}\right)$

$\mathrm{Q}$ : activity quotient of compounds involved in the reaction.

We use the measured composition of the sedimentary pore fluid to determine values of $Q$.

For a more complete overview of in situ Gibbs energy-of-reaction calculations in subseafloor sediment, see Wang et al. ${ }^{87}$.

\section{Calculation of organic oxidation rates (net rates of $\mathrm{O}_{2}$ reduction and DIC} production). We calculated the vertical distribution of net $\mathrm{O}_{2}$ reduction rates at nine sites where the sediment is oxic from seafloor to basement and the vertical distribution of DIC production rates at seven sites where the subseafloor sediment is anoxic (see Supplementary Fig. 3 for site locations). Dissolved $\mathrm{O}_{2}$ concentrations are from Røy et al. ${ }^{47}$ and D'Hondt et al. ${ }^{88}$. DIC concentrations are from ODP Leg 201 (ref. ${ }^{35}$ ), and the Proceedings of the IODP Expedition 323 (Sites U12343, $\mathrm{U} 1345)^{54}$ and IODP Expedition 329 (Site U1371 (ref. $\left.{ }^{34}\right)$ ).

The net rates are calculated using the MatLab program and numerical procedures of Wang et al. ${ }^{89}$, modified by using an Akima spline, rather than a 5 -point running mean, to generate a best-fit line to the chemical concentration data. Details of the calculation protocol for $\mathrm{O}_{2}$ production rates and DIC production rates are respectively described in the supplementary information of D'Hondt et al. ${ }^{88}$ and in Walsh et al. ${ }^{90}$. The DIC reaction rates and their first standard deviations calculated for the seven sites are given in Supplementary Table 7.

To facilitate comparisons of radiolytic chemical rates to net DIC production rates, rates are converted to electron equivalents (2 electrons per $\mathrm{H}_{2}, 4$ electrons per $\mathrm{O}_{2}, 4$ electrons per organic $\mathrm{C}$ oxidized).

Estimation of sediment ages. We estimated sediment ages for Sites U1343 and U1343 using the sediment-age model of Takahashi et al..$^{54}$, which is based on biostratigraphic and magnetostratigraphic data. Because detailed chronostratigraphic data are not available for the remaining sites (Equatorial Pacific sites (1225 and 1226), Peru Trench Site 1230 and Peru Basin Site 1231, South Pacific sites U1365, U1366, U1367, U1369, U1370, and U1371, North Pacific sites EQP9 and EQP10, and North Atlantic sites KN223-11 and KN223-12), we used the mean sediment accumulation rate for each of these sites (Supplementary Fig. 3) to convert its sediment depth (in meters below seafloor) to sediment age (in millions of years, Ma). Mean sediment accumulation rate was calculated by dividing sediment thickness by basement age ${ }^{91}$ (Supplementary Table 8). For Sites 1225, 1226 , 1230, 1231, U1365, U1366, U1367, U1369, U1370, and U1371, sediment thickness was determined by drilling to basement ${ }^{34,35}$. For Sites EQP9, EQP10, KN223-11, and KN223-12, sediment thicknesses were determined from acoustic basement reflection data.

\section{Data availability}

Sedimentary radioactive element content datasets [U (ppm); Th (ppm); K (reported as wt $\% \mathrm{~K}_{2} \mathrm{O}$ )] can be retrieved from the EarthChem SedDB data repository (https://doi.org/ 10.1594/IEDA/100603). Code and datasets for the global estimate of radiolytic $\mathrm{H}_{2}$ production are available at https://code.usgs.gov/vsc/publications/flinders_a/H2-seafloorestimator.

Received: 22 May 2020; Accepted: 13 January 2021; Published online: 26 February 2021

\section{References}

1. Spinks, J. W. T. \& Woods, R. J. An Introduction to Radiation Chemistry 3rd edn (Wiley-Interscience, 1990).

2. Blair, C. C., D'Hondt, S., Spivack, A. J. \& Kingsley, R. H. Radiolytic hydrogen and microbial respiration in subsurface sediments. Astrobiology 7, 951-970 (2007).

3. Morita, R. Y. Is H2 the universal energy source for long-term survival? Microb Ecol. 38, 307-320 (1999).

4. Türke, A., Nakamura, K. \& Bach, W. Palagonitization of basalt glass in the flanks of mid-ocean ridges: implications for the bioenergetics of oceanic intracrustal ecosystems. Astrobiology 15, 793-803 (2015).

5. Pastina, B. \& LaVerne, J. A. Effect of molecular hydrogen on hydrogen peroxide in water radiolysis. J. Phys. Chem. A 105, 9316-9322 (2001).

6. Crumière, F. et al. LET effects on the hydrogen production induced by the radiolysis of pure water. Radiat. Phys. Chem. 82, 74-79 (2013).

7. Lefticariu, L., Pratt, L. A., LaVerne, J. A. \& Schimmelmann, A. Anoxic pyrite oxidation by water radiolysis products - A potential source of biosustaining energy. Earth Planet. Sci. Lett. 292, 57-67 (2010).

8. Kumagai, Y. et al. Hydrogen production in gamma radiolysis of the mixture of mordenite and seawater: fukushima NPP accident related. J. Nucl. Sci. Technol. 50, 130-138 (2013).

9. LaVerne, J. A. \& Tandon, L. H2 production in the radiolysis of water on UO2 and other oxides. J. Phys. Chem. B 107, 13623-13628 (2003).

10. Essehli, R. et al. $\mathrm{H} 2$ production by $\gamma$ and $\mathrm{He}$ ions water radiolysis, effect of presence TiO2 nanoparticles. Int. J. Hydrog. Energy 36, 14342-14348 (2011)

11. Costagliola, A. et al. Radiolytic dissolution of calcite under gamma and helium ion irradiation. J. Phys. Chem. C 121, 24548-24556 (2017).

12. Lin, L. H. et al. Radiolytic $\mathrm{H} 2$ in continental crust: nuclear power for deep subsurface microbial communities. Geochem. Geophys. Geosyst. 6 (2005).

13. Lollar, B. S., Onstott, T. C., Lacrampe-Couloume, G. \& Ballentine, C. The contribution of the Precambrian continental lithosphere to global $\mathrm{H} 2$ production. Nature 516, 379 (2014). 
14. Lin, L.-H. et al. Long-term sustainability of a high-energy, low-diversity crustal biome. Science 314, 479-482 (2006).

15. Inagaki, F. et al. Exploring deep microbial life in coal-bearing sediment down to $2.5 \mathrm{~km}$ below the ocean floor. Science 349, 420-424 (2015).

16. Magnabosco, C. et al. The biomass and biodiversity of the continental subsurface. Nat. Geosci. 11, 707 (2018).

17. Kallmeyer, J., Pockalny, R., Adhikari, R. R., Smith, D. C. \& D’Hondt, S. Global distribution of microbial abundance and biomass in subseafloor sediment. Proc. Natl Acad. Sci. USA 109, 16213-16216 (2012).

18. Petrik, N. G., Alexandrov, A. B. \& Vall, A. I. Interfacial energy transfer during gamma radiolysis of water on the surface of $\mathrm{ZrO} 2$ and some other oxides. J. Phys. Chem. B 105, 5935-5944 (2001).

19. LaVerne, J. A. \& Tandon, L. H2 production in the radiolysis of water on $\mathrm{CeO} 2$ and $\mathrm{ZrO}$. J. Phys. Chem. B 106, 380-386 (2002).

20. Le Caër, S. Water radiolysis: influence of oxide surfaces on $\mathrm{H} 2$ production under ionizing radiation. Water 3, 235-253 (2011).

21. Pastina, B. \& LaVerne, J. A. Hydrogen peroxide production in the radiolysis of water with heavy ions. J. Phys. Chem. A 103, 1592-1597 (1999).

22. Li, L. et al. Sulfur mass-independent fractionation in subsurface fracture waters indicates a long-standing sulfur cycle in Precambrian rocks. Nat. Commun. 7, 1-9 (2016).

23. Koubek, E. et al. Kinetics and mechanism of the spontaneous decompositions of some peroxoacids, hydrogen peroxide and t-butyl hydroperoxide. J. Am. Chem. Soc. 85, 2263-2268 (1963).

24. Navalon, S., Alvaro, M. \& Garcia, H. Heterogeneous Fenton catalysts based on clays, silicas and zeolites. Appl. Catal. B Environ. 99, 1-26 (2010).

25. Do, S.-H., Batchelor, B., Lee, H.-K. \& Kong, S.-H. Hydrogen peroxide decomposition on manganese oxide (pyrolusite): kinetics, intermediates, and mechanism. Chemosphere 75, 8-12 (2009).

26. Cadena, F. \& Peters, R. W. Evaluation of chemical oxidizers for hydrogen sulfide control. J. Water Pollut. Control Fed. 1259-1263 (1988).

27. D'Hondt, S., Pockalny, R., Fulfer, V. M. \& Spivack, A. J. Subseafloor life and its biogeochemical impacts. Nat. Commun. 10, 1-13 (2019).

28. Madigan, M. T., Bender, K. S., Buckley, D. H., Sattley, W. M. \& Stahl, D. A. Brock Biology of Microorganisms 15th edn (Pearson, 2018).

29. Caccavo, F., Blakemore, R. P. \& Lovley, D. R. A hydrogen-oxidizing, Fe(III)reducing microorganism from the Great Bay Estuary, New Hampshire. Appl. Environ. Microbiol. 58, 3211-3216 (1992).

30. Khademian, M. \& Imlay, J. A. Escherichia coli cytochrome c peroxidase is a respiratory oxidase that enables the use of hydrogen peroxide as a terminal electron acceptor. Proc. Natl Acad. Sci. USA 114, E6922-E6931 (2017).

31. Imlay, J. A. The molecular mechanisms and physiological consequences of oxidative stress: lessons from a model bacterium. Nat. Rev. Microbiol. 11, 443-454 (2013).

32. Hancock, J. T., Desikan, R. \& Neill, S. J. in Role of reactive oxygen species in cell signalling pathways. Biochemical Society Transactions 29, 345-349 (2001).

33. D'Hondt, S. et al. Presence of oxygen and aerobic communities from sea floor to basement in deep-sea sediments. Nat. Geosci. 8, 299 (2015).

34. D'Hondt, S., Inagaki, F. \& Zarikian, C. A. Expedition 329. Proc. Ocean Drill. Program 329 http://publications.iodp.org/proceedings/329/329bib.htm (2011).

35. D'Hondt, S., Jørgensen, B. B. \& Miller, D. J. Leg 201. Proc. Ocean Drill. Program 201 http://www-odp.tamu.edu/publications/citations/cite201.html (2003).

36. Adhikari, R. R. et al. Hydrogen utilization potential in subsurface sediments. Front. Microbiol. 7, 8 (2016).

37. Orsi, W. D., Edgcomb, V. P., Christman, G. D. \& Biddle, J. F. Gene expression in the deep biosphere. Nature 499, 205 (2013).

38. Riedinger, N. et al. Sulfur cycling in an iron oxide-dominated, dynamic marine depositional system: the Argentine continental margin. Front. Earth Sci. 5, 33 (2017).

39. Batzke, A., Engelen, B., Sass, H. \& Cypionka, H. Phylogenetic and physiological diversity of cultured deep-biosphere bacteria from equatorial Pacific Ocean and Peru Margin sediments. Geomicrobiol. J. 24, 261-273 (2007).

40. Cleaves, H. J. II et al. Mineral-organic interfacial processes: potential roles in the origins of life. Chem. Soc. Rev. 41, 5502-5525 (2012).

41. Milliken, R. E. et al. Opaline silica in young deposits on Mars. Geology 36, 847-850 (2008).

42. Mustard, J. F. et al. Hydrated silicate minerals on Mars observed by the Mars Reconnaissance Orbiter CRISM instrument. Nature 454, 305-309 (2008).

43. Ruff, S. W. Spectral evidence for zeolite in the dust on Mars. Icarus 168, 131-143 (2004).

44. Talley, L. D. Hydrographic Atlas of the World Ocean Circulation Experiment (WOCE): Volume 2: Pacific Ocean (WOCE International Project Office Southampton, 2007).

45. Koltermann, K. P., Gouretski, V. \& Jancke, K. Hydrographic Atlas of the World Ocean Circulation Experiment (WOCE): Volume 3: Atlantic Ocean (National Oceanography Centre, 2011).
46. Murray, R. W. \& KN223 Shipboard Science Party. R/V Knorr Cruise KN223. Cruise Report (2014).

47. Røy, H. et al. Aerobic microbial respiration in 86-million-year-old deep-sea red clay. Science 336, 922-925 (2012).

48. Cheshire, H. \& Thurow, J. High-resolution migration history of the Subtropical High/Trade Wind system of the northeastern Pacific during the last 55 years: Implications for glacial atmospheric reorganization. Paleoceanography 28, 319-333 (2013).

49. Leventer, A., Williams, D. F. \& Kennett, J. P. Dynamics of the Laurentide ice sheet during the last deglaciation: evidence from the Gulf of Mexico. Earth Planet. Sci. Lett. 59, 11-17 (1982).

50. Sigurdsson, H., Sparks, R. S. J., Carey, S. N. T. \& Huang, T. C. Volcanogenic sedimentation in the Lesser Antilles arc. J. Geol. 88, 523-540 (1980).

51. Westerhoff, P., Mezyk, S. P., Cooper, W. J. \& Minakata, D. Electron pulse radiolysis determination of hydroxyl radical rate constants with Suwannee River fulvic acid and other dissolved organic matter isolates. Environ. Sci. Technol. 41, 4640-4646 (2007).

52. Dunlea, A. G. et al. Dust, volcanic ash, and the evolution of the South Pacific Gyre through the Cenozoic. Paleoceanography 30, 1078-1099 (2015).

53. Kyte, F. T., Leinen, M., Heath, G. R. \& Zhou, L. Cenozoic sedimentation history of the central North Pacific: Inferences from the elemental geochemistry of core LL44-GPC3. Geochim. Cosmochim. Acta 57, 1719-1740 (1993).

54. Takahashi, K., Ravelo, A. C. \& Zarikian, C. A. IODP Expedition 323-Pliocene and Pleistocene Paleoceanographic changes in the Bering Sea. Proc. Integr. Ocean Drill. Program 11 (2011).

55. Li, Y. H. \& Schoonmaker, J. E. Chemical Composition and Mineralogy of Marine Sediments. 1-35 https://doi.org/10.1016/B0-08-043751-6/07088-2 (2003).

56. Erlank, A. et al. Handbook of Geochemistry (Springer-Verlag, 1978).

57. Naval-Oceanographic-Office. Database Description for Bottom Sediment Type. OAML-DBD-86 (Acoustics Division, Stennis Space Center, Mississsippi, 2003).

58. Martin, K. M., Wood, W. T. \& Becker, J. J. A global prediction of seafloor sediment porosity using machine learning. Geophys. Res. Lett. 42, 10,640-610,646 (2015).

59. Divins, D. L. Total Sediment Thickness of the World's Oceans \& Marginal Seas (NOAA National Geophysical Data Center, 2003).

60. Masters, G. \& Laske, G. On bias in surface wave and free oscillation attenuation measurements. EOS Trans. Am. Geophys. Union 78, F485 (1997).

61. Dutkiewicz, A., Müller, R. D., O'Callaghan, S. \& Jónasson, H. Census of seafloor sediments in the world's ocean. Geology 43, 795-798 (2015).

62. DeMaster, D. J. The accumulation and cycling of biogenic silica in the Southern Ocean: revisiting the marine silica budget. Deep Sea Res. II Top. Stud. Oceanogr. 49, 3155-3167 (2002).

63. Barker, P. \& Kennett, J. Leg 113 - initial reports. Proc. Ocean Drill. Program 113, 1033 (1988).

64. O'Brien, P. et al. Shipboard Scientific Party. Leg 188 summary: Prydz Bay-Cooperation Sea, Antarctica. Proc. Ocean Drill. Program 188, 1-65 (2001).

65. Barron, J. \& Larsen, B. Leg 119 - initial reports. Proc. Ocean Drill. Program 119, 942 (1989).

66. Backman, J., Moran, K. \& Mayer, L. A. Expedition 302 - summary. Proc. Ocean Drill. Program 302 (2006).

67. Myhre, A., Thiede, J. \& Firth, J. Volume 151 initial reports - North AtlanticArctic gateways. Proc. Ocean Drill. Program 151 (1995).

68. Thiébault, F. et al. Analysis of sedimentary facies, clay mineralogy, and geochemistry of the Neogene-Quaternary sediments in Site 645, Baffin Bay. Proc. Ocean Drill. Prog. Sci. Results 105, 83-100 (1989).

69. Barker, P., Dalziel, I. \& Sherwood, W. DSDP Leg 36 - Site 326. In Deep Sea Drilling Program - DSDP Proceedings 36 (1977).

70. Frey, F., Coffin, M., Wallace, P. \& Weis, D. Leg 183 synthesis: Kerguelen Plateau-Broken Ridge-a large igneous province - Scientific results. Proc. Ocean Drill. Program 183, 1-48 (2003).

71. Carter, R., McCave, I., Richter, C. \& Carter, L. Leg 181- Site 1121 - the Campbell "Drift." - initial reports. Proc. Ocean Drill. Program 181 (1999).

72. Keigwin, L., Rio, D. \& Acton, G. Leg 172 - Bermuda Rise and Sohm abyssal plain, Sites 1063 and 1064 - Initial Reports. Proc. Ocean Drill. Program 172, 251 (1998).

73. Schmincke, H., Weaver, P. \& Firth, J. Site 951 - initial reports. Proc. Ocean Drill. Program 157 (1995).

74. Curry, W., Shackleton, N. \& Richter, C. Leg 154 Synthesis. In Proceedings ODP, Initial Reports Vol. 154, 421-442 (1995).

75. Pokras, E. M. \& Ruddiman, W. F. Leg 108 - Site 66 - initial reports. Proc. Ocean Drill. Program 108, 143-148 (1988).

76. Bown, P. R. \& Newsam, C. Calcareous nannofossils from the Eocene North Atlantic Ocean (IODP Expedition 342 Sites U1403-1411). J. Nannoplankton Res. 37, 25-60 (2017).

77. Channell, J.E.T., Kanamatsu, T., Sato, T., Stein, R., Alvarez Zarikian, C.A., Malone, M.J., and the Expedition 303/306 Scientists. Proceedings of the Integrated Ocean Drilling Program, Volume 303/306 (2010). 
78. Zabel, M. \& Schulz, H. D. Marine Geochemistry (Springer, 2000).

79. Pälike, H. et al. Expedition 320/321 summary. Proc. IODP 320/321 (2010).

80. LaRowe, D. E., Burwicz, E., Arndt, S., Dale, A. W. \& Amend, J. P. Temperature and volume of global marine sediments. Geology 45, 275-278 (2017).

81. Hantschel, T. \& Kauerauf, A. I. Fundamentals of Basin and Petroleum Systems Modeling (Springer Science \& Business Media, 2009).

82. Whittaker, J. M., Goncharov, A., Williams, S. E., Müller, R. D. \& Leitchenkov, G. Global sediment thickness data set updated for the Australian-Antarctic Southern Ocean. Geochem. Geophys. Geosyst. 14, 3297-3305 (2013).

83. Laske, G \& Masters, G. A global digital map of sediment thickness. EOS Trans. Am. Geophys. Union 78, F483 (1997).

84. GEBCO. General Bathymetric Chart of the Oceans (GEBCO)- Grid (Canadian Hydrographic Service, 2014).

85. Lovley, D. R. \& Goodwin, S. Hydrogen concentrations as an indicator of the predominant terminal electron-accepting reactions in aquatic sediments. Geochim. Cosmochim. Acta 52, 2993-3003 (1988).

86. Hoehler, T. M., Alperin, M. J., Albert, D. B. \& Martens, C. S. Thermodynamic control on hydrogen concentrations in anoxic sediments. Geochim. Cosmochim. Acta 62, 1745-1756 (1998).

87. Wang, G., Spi3vack, A. J. \& D'Hondt, S. Gibbs energies of reaction and microbial mutualism in anaerobic deep subseafloor sediments of ODP Site 1226. Geochim. Cosmochim. Acta 74, 3938-3947 (2010).

88. D'Hondt, S. et al. Presence of oxygen and aerobic communities from sea floor to basement in deep-sea sediments. Nat. Geosci. 8, 299-304 (2015).

89. Wang, G., Spivack, A. J., Rutherford, S., Manor, U. \& D'Hondt, S. Quantification of co-occurring reaction rates in deep subseafloor sediments. Geochim. Cosmochim. Acta 72, 3479-3488 (2008).

90. Walsh, E. A. et al. Relationship of bacterial richness to organic degradation rate and sediment age in subseafloor sediment. Appl. Environ. Microbiol. 82, 4994-4999 (2016).

91. Müller, R. D., Sdrolias, M., Gaina, C. \& Roest, W. R. Age, spreading rates, and spreading asymmetry of the world's ocean crust. Geochem. Geophys. Geosyst. 9 (2008).

\section{Acknowledgements}

We thank ODP Leg 201, IODP Expeditions 323 and 329, RV Knorr expeditions 195-3 and 223, RV Endeavor expeditions 20, 32, and 534, and RV Marion Dufresne MONA expedition for samples and data. We thank the URI Marine Geological Samples Laboratory for samples and the staff of the Rhode Island Nuclear Science Center for advice, materials, and experimental space. We thank Dennis Graham for help in setting up experiments. This project was funded by the US National Science Foundation (through grant NSF-OCE-1130735 and the Center for Deep Dark Energy Biosphere Investigations [C-DEBI; grant NSF-OCE-0939564]); the National Aeronautics and Space Administration (grant NNX12AD65G); the U.S. Science Support Program, IODP; and a
Schlanger Ocean Drilling Fellowship to J.F.S. This is a contribution to the Deep Carbon Observatory (DCO). It is C-DEBI publication 553

\section{Author contributions}

J.F.S. designed and executed the study with significant input from S.D. and A.J.S. S.D. initiated the project and, with R.W.M. and A.J.S., generated the project funding. J.F.S., S.D., and A.J.S. wrote the manuscript. J.F.S., D.C.S., A.D., C.H., and R.W.M. collected and analyzed the data. J.F.S., A.F., and R.P. performed integrative analyses. All authors provided editorial comments on the manuscript.

\section{Competing interests}

The authors declare no competing interests.

\section{Additional information}

Supplementary information The online version contains supplementary material available at https://doi.org/10.1038/s41467-021-21218-z.

Correspondence and requests for materials should be addressed to J.F.S.

Peer review information Nature Communications thanks Barbara Sherwood Lollar, Matthew O Schrenk, and Andreas Türke for their contributions to the peer review of this work.

Reprints and permission information is available at http://www.nature.com/reprints

Publisher's note Springer Nature remains neutral with regard to jurisdictional claims in published maps and institutional affiliations.

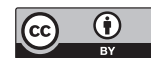

Open Access This article is licensed under a Creative Commons Attribution 4.0 International License, which permits use, sharing, adaptation, distribution and reproduction in any medium or format, as long as you give appropriate credit to the original author(s) and the source, provide a link to the Creative Commons license, and indicate if changes were made. The images or other third party material in this article are included in the article's Creative Commons license, unless indicated otherwise in a credit line to the material. If material is not included in the article's Creative Commons license and your intended use is not permitted by statutory regulation or exceeds the permitted use, you will need to obtain permission directly from the copyright holder. To view a copy of this license, visit http://creativecommons.org/ licenses/by/4.0/.

(C) The Author(s) 2021 